\title{
The Specific Character of Political Power under "Who Do I Obey Politically?"
}

\author{
Oprea-Valentin Buşu \\ Faculty of Sociology and Social Work, University of Bucharest, Bulevardul Regina Elisabeta 4-12, \\ Bucharest 030018, Romania \\ E-mail address: valentino_busu@yahoo.ro
}

\begin{abstract}
The study takes into account the organizational capacity, the numerical support, the competence, the specialized knowledge, the information control, the occupation of certain social positions, the control of the means of force and the very reputation for holding power, all these seen as power resources. It is noticed the existence of a potential power that depends on certain qualities, skills and competencies and the existence of a manifest power involving the feedback as far as the exercise of power is concerned and obedience. The conclusion is that the specific of the political power derives from the answer to whom do I obey politically?
\end{abstract}

Keywords: power; political power; social competence; communication

\section{INTRODUCTION}

In its most general acceptation, the notion of power does not have a single application domain: we can thus speak about the power of nature, as well as the power over human beings. Within this latter register, our interest can be retained both by the self-control proven by a particular agent, as well as by their power available towards other social actors. This plurality of uses requires different shades that a semanticist would certainly notice, but here, the notion of power often serves to denote the ability of a given actor to reach the intended results and, in particular, to achieve effective actions, however, Bertrand Russell was thinking about this type of significance when he proposed the "production of intended effects" as a distinguishing criterion of power (Boudon, 1997, p. 221).

In accordance with this definition of an exemplary concision, the tangible sign of an agent's power is given by the correlation between the results and his own desires. Some authors, especially among philosophers, invite us to limit ourselves to this generic concept, or at least get from it, even when their primary concern is the social and political power: thus, Alvin Goldman begins by exploring what he calls "the functional dependencies between the desires of an agent and the results (they get) to a given problem."

We note that there is another possibility of adopting a general definition of power, with emphasis on the possibility to have appropriate means, without any explicit reference to the actor's social intentions: it is, as you know, the path chosen by Hobbes for whom the "power 
of a man (if we take the word in its universal acceptation) is the present means necessary to obtain any future apparent good" (Leviathan, chap. X).

B. de Jouvenel defines the "pure power" through the "commandment existing in itself and for itself". The power can also be highlighted within the relationship between two or more people, the power over someone. This inter-actionist perspective originates back in a famous definition advanced by Max Weber: "the power is the chance that makes the own will prevail within a social relationship, even in spite of all resistance; it makes little difference what this chance must have as support." The power over someone is the power to do something. It is a capacity both of material (to work, to do a work) or legal action (to have recognized expertise in law). In reality, the power to do something does not necessarily appear in a relationship when it is only a physical or intellectual ability, likely to be achieved in a project (Milca).

According to the inter-actionist conception, the focus is on the dissymmetry relationship demonstrated by the power. First, the power implies the presence of at least two persons. Then, the power is not an immutable essence or abstract nature. It is a practice, a social experience. Finally, the exercise of power arouses a detected reaction found in the political behavior. It is notable the definition of the American political scientist R. Dahl: "A exercises power over B to the extent that A gains from B the action Y that the latter would not have done it other way". This approach allows to link the notion of power (or jurisdiction) and that of responsabiliy. That who exercises power is or should be responsible for his acts and their consequences, whether in some cases the acts are committed by performers following orders (Siminică \& Traistaru, 2013< Vl[du'escu, 2014).

The exercise of power can produce not only observable behaviors, but also non - decision, and the more intense, it can cause the absence of any visible litigation. The process to get to silence or suppress the possible complaint is very complex, combining legal, psychological, sociological and cultural elements. The exercise of power often leads to limiting individual freedom. In this context, the consent of those against whom the power is exercised becomes utmost importance. If $\mathrm{B}$ agrees to behave as $\mathrm{A}$ has suggested, can we say that $\mathrm{B}$ is subject to the power of $\mathrm{A}$ ? The threshold between constraint and consent is not always clearly defined. B may agree to behave in a certain way on purpose if A suggests so, (well or badly understood), from ignorance or lack of the accurate data of the situation, or even blindness. The social and psychological context of consent must be established and known to spot, from a sociological point of view, the actual power relationship. Individuals prefer to believe that they surrender voluntarily or are forced to be subordinate. But that who exercises power can delude themselves as well (Milca, 2001; Paun, 2013; Vlăduţescu, 2013a).

A power relationship may be presented as a commandment to the extent that the one on whom the power is exercised has to choose to obey the order or risk being penalized (i.e. the order given by an officer to another soldier). Is the injunction a necessary and sufficient condition of the prescribed behavior? The authentic injunction reveals when the subject of the order has to choose between two attitudes: to fold in front of the order, adopting a prescribed behavior, or to expose himself to a sentence. The latter may authoritatively deal with the deprivation of an expected benefit or produce prejudice (the deprivation of liberty or material goods). Disobedience leads to deterioration of the subordinate. If the power is exercised in a non-constraining manner and which is known as influence, the individual is placed in front of a different alternative when he either adopts the suggested behavior taking advantage of certain benefits (material or symbolic rewards, favors on the part of an influential figure), receiving psychosocial gratuity (less anxiety, self-esteem, stability of the own condition) or does not adopt the suggested behavior and deprives himself of a reward, thus suffering a deterioration of his current situation. The influence relationship excludes the constraint and is based on 
seduction and persuasion. Manipulation is a variation of persuasion which demonstrates a clandestine nature (Măgureanu, 2006; Frigioiu, 2010). A influences B, without B's consciousness of direction or order it is taking at the suggestion of A. Manipulation involves an unfair manner to abuse the trust of individuals, not allowing them to carefully examine the situation and take an independent decision in wittingly.

\section{THE SPECIFIC CHARACTER OF POLITICAL POWER}

The political nature of power does not reveal itself objectively and absolutely, but it results from an action of assignment and contextualized imputation, intended to make the role of the leader be awarded (e.g. a king that nobody believes him king no longer exercises any power). The political power origins back in conflicts and tensions that manifest in every human society and require appropriate solutions. There are archetypal forms of conflict between generations, between different families (tribes, clans, sedentary and nomadic populations etc.). There is a conflict between individuals and groups in situations of inequality. The objective or negative shortage will always generate feelings of frustration and resentments. Finally, a presumptive threat from an external enemy, perceived in terms of otherness and diffuse hostility obliges also a social mobilization that strengthens the foundations of power. Conflicts emerge power relations, hierarchies that by time become social stakes fueling the political competition. The political power becomes, in these circumstances, a regulatory court of disputes and disagreements, conflicting relations in society (Dima, Grabara \& Vlăduţescu, 2012).

The power relationship is by definition asymmetric as it assumes that B conforms to the expectations or behavior, if not to the explicit intentions, of A. But as we have seen, the field of this relationship can be very small: but it does not mean that, in other areas, the relationship may not be reversed. Social life gives us a lot of examples of this alternation which tends to fade - without abolish them - the hierarchical effects inherent in any power relation. So the asymmetry instituted of power is not incompatible with interdependence, at least with some degree of interdependence. We must, however, recognize that this balances game can be much harder established in an organization where the power gets a formal character, and its very existence becomes problematic in the overall level of political power which is, in modern societies, closely linked to the state institution: indeed we know very well that both the creation and retention of a counterweight system is one of the permanent objectives of the policy (Bădescu, 2011; Smarandache \& Vlăduţescu, 2014).

So it is not legitimate, as Giddens pointed (1976), to assert that power involves conflict according to Weber's example authority. And it should be added, along the British sociologist, that this last statement in itself, like Weber's interpretation on which it is based, is questionable: the mere fact that it is empirically frequent, the link between power and conflict should not be considered inevitable from the beginning. In our opinion, this tendency to reduce, as Steven Lukes does (1974), any exercise of power to an underlying conflict of interest is a little daring, whether the conflict is apparently hidden or latent: the ability with which Steven Lukes makes this implementation does not mask the unilateral view on power, which is the base of this reductive operation (Vlăduţescu, 2004; Vlăduţescu, 2006). But it is equally, if not more illusory to fade the conflict nature that power relations often have: the antagonistic dimension is certainly not constitutive of power relations, but it is too frequent not to be considered significant. In this regard, of Max Weber's definition may be considered exemplary (Măgureanu, 1997). 
Instead, it may be considered too general, to the extent of considering neither any power bases, as Weber takes care to point out, nor - this time simply by omission - the ways of interaction that power can create. Thus understood, the concept of power remains, the observation belongs to Weber, "amorphous from a sociological point of view" and therefore, in itself, it has a limited value: it is thus desirable to try a stricter definition. In this respect, it is not without interest to recall the distinction between advice and order, (operated by Hobbes in De Cive) and further developed in Chapter XXV of Leviathan. "Or, Hobbes writes, the advice is a kind of order, and the reason why we obey it comes from the very thing that is ordered, while the command is an order, and the reason why we obey it comes from the will of that commander." Hobbes relies on this distinction to determine that the law is like the command; and comments the notable differences he finds between law and advice as follows: "The first belongs to the man who has power over those on whom it is intended, and the latter comes from a person who has no authority over that man whom he/she advises. We are obliged to do the duty which the law orders, but we use our free will when we are ordered by advice." From this text we can retain some significant observations for our discussion. First, the command - obedience relations are in the center of power relations, even though they are not limited to them, and the implicit recognition of this is the introduction of domination (Herrschafi), by Weber, after the notion of power, that involves only, according to the following passage in Economy and society, "the presence of a man! Who successfully commands the others" (Weber, 1992, p. 56). Then, the respecting of one party of the orders given by the other party generally depends less on their particular content and more on the very source from which they come. The essential problem B is facing is not finding the intrinsic reasons for a possible acceptance of the application of $\mathrm{A}$, but identifying extrinsic signs related to the characteristics of A, which causes B to obey.

\section{CONCLUSION}

It is excluded from the field of power the persuasion that depends solely on the quality of the arguments used by A to persuade B. Accepting the value of an argument is not a phenomenon of the same kind with the dependency relation to a person or group. Despite the fact that rational persuasion is not a form of power, B's adopting the behavior in accordance with the orders or, more generally, the expectation of A is, in many cases, perfectly reasonable. The power criterion is a submissive criterion. We identify the specific character of power not in the question that each and every individual asks "What arguments should be accepted ?", but rather "Who should I obey?"

\section{References}

[1] Borowski A. (a), International Letters of Social and Humanistic Sciences 3 (2013) 69-74.

[2] Boudon, R. (1997). Tratat de sociologie. Bucureşti: Humanitas.

[3] Konfisahor, A., Psihologia puterii, Bucureşti, Euro Press Group, 2008.

[4] Donovan A. McFarlane, International Letters of Social and Humanistic Sciences 4 (2013) 35-44. 
[5] Nowicka-Scowron Maria, Dima Ioan Constantin, Vlăduţescu Ştefan, International Journal of Management Sciences and Business Research 1(8) (2012) 27-35.

[6] Borowski A. (b), International Letters of Social and Humanistic Sciences 2 (2014) 110-121.

[7] Vlăduţescu Ştefan (2004). Argumentaţia şi demonstraţia, ca moduri de impunere. Craiova: Editura Sitech.

[8] Vlăduţescu Ştefan (2013a). Three Diachronic Paradigms of Communication. International.

[9] Frigioiu N. (2010). Politologie şi doctrine politice. Bucureşti: Editura Economică.

[10] Frigioiu N. (2010). Puterea imaginii şi imaginarul Puterii. Bucureşti: Editura Economică.

[11] Gueguen N. (2007). Psihologia manipulării şi a supunerii. Iaşi: Editura Polirom.

[12] Vlăduţescu Ştefan, Ciupercă Ella Magdalena (2013). Next Flood Level of

Communication: Social Networks. Aachen: Shaker Verlag.

[13] Greene R. (2000). Succes şi putere. Bucureşti: Teora.

[14] Măgureanu Virgil (2003). Declinul sau apoteoza puterii? RAO.

[15] Teodorescu Gheorghe (2000). Putere, autoritate şi comunicare politică. Bucureşti: Nemira.

[16] Tittenbrun J., International Letters of Social and Humanistic Sciences 2 (2014) 20-40.

[17] Dima, Ioan Constantin; Vlăduţescu, Ştefan (2012). Persuasion elements used in logistical negotiation: Persuasive logistical negotiation. Saarbrucken: LAP Lambert Academic Publishing. Dima, IC \& Vladutescu, Stefan (2013a). Some Consequences of the Negative Journalistic Communication in the Austerity Period. Science Series Data Report, 5(7), 2-7.

[18] Mangra M. G., Cotoc E. A., Traistaru A. (2013). Sustainable Economic Development Through Environmental Management Systems Implementation. Journal.

[19] Borowski A. (c), International Letters of Social and Humanistic Sciences 4 (2013) 70-74.

[20] Ciupercă, Ella Magdalena, \& Vlăduţescu, Ştefan (2010). Securitatea naţională şi manipularea opiniei publice. Bucureşti: Editura Didactică şi Pedagogică.

[21] Măgureanu, Virgil (2006). Sociologie politică. RAO.

[22] Smarandache, Florentin, \& Vlăduţescu, Ştefan (2014). Neutrosophic Emergences and Incidences in Communication and Information. Saarbrucken: LAP Lambert Academic Publishing. 
[23] Paun Mihaela Gabriela (2013). Changes in Management as an Instrument of Educational Intervention. European.

[24] Măgureanu V. (1997). Studii de sociologie politică. BucureŞti: Editura Albatros.

[25] Vlăduţescu Ştefan (d), International Letters of Social and Humanistic Sciences 7 (2014) 8-13.

[26] Măgureanu V. (2006). Sociologie politică. Bucureşti: Editura Rao.

[27] Siminică Marian, Traistaru Aurelia (2013). Self-Directed Learning in Economic Education. International.

[28] Milca M. (2001). Geneza teoriei elitelor. Provocarea neomachiavellienilor. Bucureşti: Editura Economică.

[29] Vlăduţescu Ştefan (2013a). A Completion to the Traditions Matrix-Standard - R. T. Craig, Induced by the Transformation of Communication-as-a-Field Membrane in Communication-as-a-Universe Membrane. American.

[30] Nowicka-Scowron Maria, Dima Ioan Constantin, Vlăduţescu Ştefan, International Journal of Management Sciences and Business Research 1(8) (2012) 27-35.

[31] Vlăduţescu Ştefan (2013b). The Communication Membranes. European .

[32] Pretorian Cristina, Ionescu Dan, International Letters of Social and Humanistic Sciences 9 (2014) 49-56.

[33] Măgureanu V. (2003). Declinul sau apoteoza puterii. Bucureşti: Editura Rao.

[34] Vlăduţescu Ştefan (2013c). Principle of the Irrepressible Emergence of the Message. Jokull.

[35] Dowding K. (1998). Puterea. Bucureşti: Editura Du Style.

[36] Măgureanu V. (2009). De la regimul comunist la regimul Iliescu. Bucureşti: Editura Rao.

[37] Milca M. (2005). Identitate românească şi europeană. Bucureşti: Editura Agir.

[38] Frigioiu N. (2008). Imaginea publică a liderilor şi instituţiilor. Bucureşti: Editura Comunicare.ro

[39] Frigioiu Nicolae (2004). Imaginea publică a liderilor şi instituţiilor politice. Bucureşti: comunicare.ro

[40] Florescu Costel (2007). Puterea personală, poziţiei, organizaţiei. Bucureşti: Editura Universitară.

[41] Vlăduţescu Ştefan (2013d). What Kind of Communication Is Philosophy. Jokull.

[42] Bădescu I. (2011). Sociologie rurală. Bucureşti: Mica Valahie. 
[43] Vlăduţescu Ştefan (2013). Message as Fundamental Discursive Commitment of Communication. Journal.

[44] Duţă Victor (2006). Puterea fără limite. Bucureşti: Editura Ştefan.

[45] Weber M. (1992). Politica, o vocaţie şi o profesie. Bucureşti: Editura Anima.

[46] Le Bon G. (2007). Psihologia mulţimilor. Editura Antet.

[47] Dima Ioan Constantin, Grabara Janusz, Vlăduţescu Ştefan (2012). Journal on Business Review 2(2) (2013) 4.

[48] Vlăduţescu Ştefan (2014). Eight computational-communicative operations of building information. Mitteilungen Klosterneuburg.

[49] Jason L. Powell, International Letters of Social and Humanistic Sciences 7 (2014) 22-30. 